\title{
Closed Capsulotomy
}

National Cancer Institute

\section{Source}

National Cancer Institute. Closed Capsulotomy. NCI Thesaurus. Code C50834.

A procedure used to treat capsular contraction that uses physical manipulation of the breast to manually rupture scar tissue and release pressure on an implant. 